\title{
Flashcard Media as The Vocabulary Introduction on Indonesian as Second Language Learner Level $I$ in Sebelas Maret University
}

\author{
Silmi Tara ${ }^{1}$, Andayani $^{2}$, Suyitno $^{3}$ \\ Sebelas Maret University \\ ${ }^{1}$ tarasilmi@student.uns.ac.ic, 2bu_anda@yahoo.com, 3yitsuyitno52@gmail.com
}

\begin{abstract}
Vocabulary is an important part in learning languages. The main capital for language learners, especially foreign languages is vocabulary mastery. One of several factors that are considered important in supporting the success of a learning is the media used in learning.This study has a purpose to explain flashcard's effectivity as an Indonesian language introduction for Indonesian as a Second language Learners (BIPA). This research uses a descriptive qualitative method using case studies. Data obtained through interviews with BIPA teachers and learners at UPT Bahasa Sebelas Maret University. Data analysis uses interactive techniques by discovering new knowledge from a collection of interviews, observations, and documents study. Data triangulation is done for validity testing. This study's results indicate that flashcards are an inviting and effective media for vocabulary introduction. This proven because the flashcard media is able to provide visualizations and illustrations related to the words. In addition, the flashcard is also able to practice a number of skills such as writing, listening and reading. The application of flashcard media becomes an advantages in language learning in the UNS UPT Bahasa BIPA program, especially in vocabulary introduction.
\end{abstract}

Keywords: Media, Teaching, Language, Flashcard, vocabulary acquisition

\section{PENDAHULUAN}

Kosakata merupakan bagian penting dalam mempelajari bahasa. Baik pengajar, pemelajar, maupun peneliti setuju dengan pendapat ini. Kata merupakan blok pembangun dan pondasi awal dari pengetahuan untuk bahasa [1]. Kosakata menjadi unsur pembangun utama dalam mempelajari bahasa. Termasuk bagi pemelajar bahasa asing, kosakata menjadi modal utama dalam mempelajari suatu bahasa, Semakin banyak kosa-kata yang dikuasai akan memberikan tingkat percaya diri yang lebih tinggi bagi pemelajar asing dalam mempelajari bahasa asing. Keadaan ini membuat penguasaan kosakata menjadi suatu tantangan baik bagi pengajar ataupun para pemelajar bahasa itu sendiri.

Satu dari beberapa faktor yang dianggap penting dalam menunjang keberhasilan sebuah pembelajaran yaitu media yang digunakan dalam pembelajaran. Media pembelajaran memiliki peran sebagai alat bantu dengan fungsi memudahkan peserta didik dalam mengasosiasikan materi pembelajaran, sebagai sumber pertanyaan dan stimulus belajar, dan sebagai salah satu 
sumber belajar peserta didik yang berisikan materi pembelajaran [2]. Media pembelajaran yang sesuai dengan kondisi pemelajar akan mampu meningkatkan minat belajar para pemelajar BIPA. Pemilihan media yang tepat tentu akan menunjang kualitas pembelajaran di kelas.

Flashcard merupakan kartu berukuran kecil dengan gambar, simbol tanda, ataupun teks guna merangsang daya ingat serta mengarahkan siswa pada hal yang berhubungan dengan gambar yang digunakan sebagai salah satu media pembelajaran [3]. Flashcard dinilai menjadi media grafis yang dirasa praktis sekaligus aplikatif. Kartu belajar sisi ganda dengan salah satu bagian berisi gambar/simbol tertentu dan bagian lainnya berisi teks yang merupakan definisi gambar tersebut dinilai mampu membantu daya ingat pemelajar BIPA pada hal yang berhubungan dengan gambar tersebut. Hal ini tentu memudahkan pemelajar mengingat kosakata yang sedang dipelajari dengan gambaran atau visual pada flashcard.

Pemelajar BIPA level I dirasa memerlukan media pembelajaran yang efektif guna menunjang penguasaan kosakata mereka. Oleh sebab itu media flashcard diharapkan mampu menjadi solusi atas permasalahan penguasaan kosakata bagi pemelajar BIPA di UPT Bahasa Universitas Sebelas Maret.

\section{METODE PENELITIAN}

Penelitian ini menggunakan metode kualitatif pendekatan studi kasus dengan objek penelitian yang merupakan peserta program BIPA level I di UPT Bahasa Universitas Sebelas Maret. Beberapa tahap pengumpulan data diantaranya berupa wawancara mendalam, pengamatan, dan studi dokumentasi. Informasi nyata yang berkaitan dengan kegiatan pengajar selama penggunaan media flashcard dalam pembelajaran diperoleh melalui tahap wawancara dan pengamatan. Sementara studi dokumentasi dilakukan guna mempelajari dokumen pengajar yang berupa hasil kerja pemelajar BIPA dan media yang digunakan. Bentuk data penelitian ini beryoa hasil wawancara, observasi, dan dokumen penelitian sebelumnya.

Triangulasi data dan pengamatan secara terus-menerus dilakukan guna memperoleh keabsahan data. Teknik triangilasi yang dilakukan yaitu teknik triangulasi sumber data. Informasi dari pengajar BIPA dan peserta BIPA dikumpulkan melalui teknik triangulasi sumber data. Tahap selanjutnya, dilakukan pengecekan, pengecekan ulang, dan pengecekan silang. Analisis data harus dilakukan secara terus menerus hingga tuntas, dan ditemukan data jenuh [4]. Tiga tahap analisis data dilakukan untuk menganalisis data dalam penelitian ini. Pertama, reduksi akan dilaksanakan secara langsung dan berangsur-angsur. Kedua, tahap penyajian data disajikan dalam bentuk uraian yang terpilah. Sementara pengambilan kesimpulan dilakukan atas dasar analisis data dan hasil diskusi peneliti bersama pengajar.

\section{HASIL DAN PEMBAHASAN}

Kosakata sebagai komponen utama pembelajaran bahasa telah menjadi objek berbagai penelitian yang masing-masing memiliki kontribusinya sendiri pada bidang tersebut, kata-kata dari bahasa, kelompok, atau bidang pengetahuan tertentu [5]. Kosakata dinilai sebagai esensi dan merupakan bagian intrinsik dari pembelajaran bahasa itu sendiri. Pembelajaran kosakata dinilai sangat penting dalam mempelajari suatu bahasa. Pengajaran kosakata pada bahasa kedua memiliki implikasi yang signifikan dalam pembelajaran bahasa kedua [6]. Kita mungkin melihat peningkatan dalam pengetahuan metakognitif yang disediakan guru untuk pelajar tentang ukuran kosakata[7]. 
Pemelajar bahasa asing level pertama diharuskan untuk mampu memahami dan menggunakan konteks perkenalan serta pemenuhan kebutuhan harian yang sederhana guna berkomunikasi dengan mitra tutur [8]. Namun pada kenyataannya, hampir keseluruhan pemelajar BIPA level I di UPT Bahasa Universitas Sebelas Maret sama sekali tidak banyak tahu mengenai kosakata dalam bahasa Indonesia. Hal ini disampaikan oleh salah satu pengajar, Ibu Sri Riwanti, M.Pd. yang mengatakan bahwa pemelajar BIPA level I mengalami berbagai kesulitan dalam mempelajari bahasa Indonesia karena masih memiliki pengetahuan yang sangat minim terhadap kosakata bahasa Indonesia. Hal ini juga diungkap beberapa mahasiswa BIPA level I seperti Mahrish yang berasal dari Turkmenistan dan Fanta yang berasal dari Sierra Lone bahwa kosa kata adalah hal yang cukup sulit dipelajari dalam bahasa Indonesia.

Hasil wawancara dengan pemelajar BIPA di UPT Bahasa UNS juga mengungkap jika hal yang paling sulit dikuasai dalam mempelajari bahasa Indonesia adalah kosakatanya. Beberapa kosakata dalam bahasa Indonesia sulit diajarkan secara langsung, terutama bagi pemelajar BIPA yang tidak menggunakan huruf latin sebagai bahasa tulis sehari-hari. Hal ini membuat mereka benar-benar kesulitan dalam menguasai kosakata bahasa Indonesia. Sehingga diperlukan media pembelajaran yang memiliki peranan penting guna mengarahkan proses pembelajaran untuk mencapai hasil yang diinginkan [9].

Penghayatan terbaik kosakata dihasilkan oleh pertemuan komprehensi dan pembentukan kata dalam konteks sekitarnya [10]. Dengan demikian, peserta mampu mengasosiasikan kata dengan konteks sesungguhnya serta dapat mengingat dan menggunakan kata tersebut lebih baik daripada hanya mempelajari secara terpisah antara kata dan maknanya. Penelitian yang dilakukan oleh Macalister [11] menyebutkan bahwa responden lebih memilih menggunakan teks dengan ilustrasi (gambar) dibandingkan dengan tek biasa. Hal ini menunjukkan jika ilustrasi dibutuhkan dalam penguasaan kosakata guna mengasosiasikan kata dengan konteks sesungguhnya.

Flashcard merupakan pembelajaran berbentuk kartu bergambar yang dilengkapi dengan kosakata [12]. Media ini mengandung sejumlah kelebihan, diantaranya: mudah dibawa, praktis, mudah diingat, dan menciptakan suasana menyenangkan [13]. Hal ini juga disampaikan oleh Angraeny bahwa media flashcard sangat membantu peserta didik dalam membuat karangan, serta membantu tercapainya tujuan dari suatu pembelajaran[14]. Media flashcard dirasa cukup praktis baik bagi pengajar maupun pemelajar bahasa. Selain penggunaannya yang mudah, flashcard dirasa menjadi salah satu media yang dapat menciptakan suasana menyenangkan dalam penggunaannya. Hal ini dibuktikan dengan kegiatan belajar-mengajar kelas BIPA level 1 di UPT Bahasa UNS, dimana para pemelajar menunjukkan sikap antusias selama menggunakan media flashcard. Dilihat dari hasil belajar, media flashcard dinilai mampu meningkatkan penguasaan kosakata pemelajar BIPA. Visualisasi dari flashcard dapat memberikan ilustrasi yang akan mempermudah pemelajar BIPA mengingat kosakata bahasa Indonesia. 


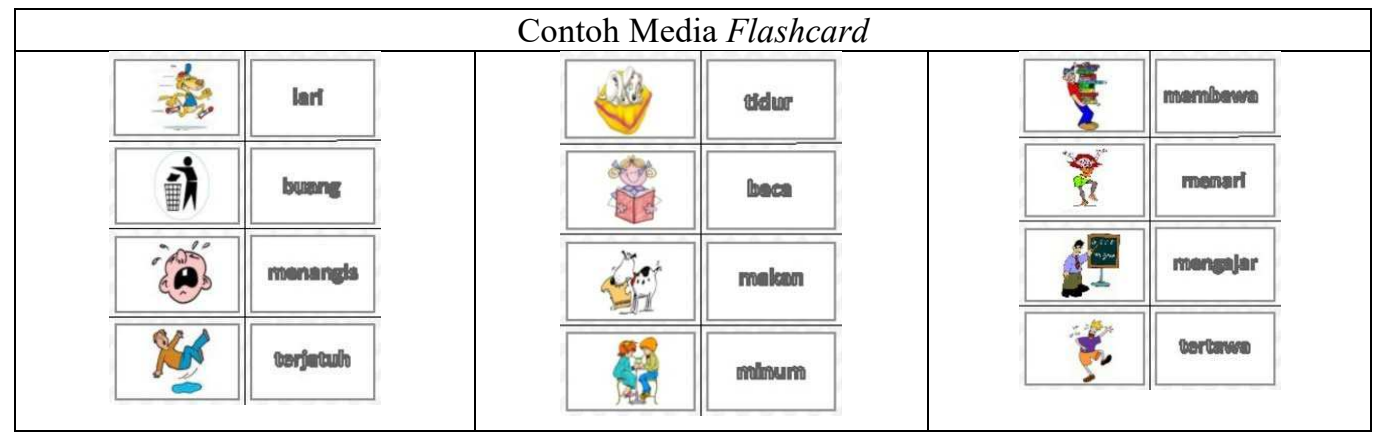

Gambar 1. Media Flascard untuk Pembelajaran BIPA

Hasil pembelajaran yang diperoleh di UPT Bahasa UNS bahwa flashcard berguna dalam membantu pemelajar asing untuk mempelajari kosakata baru. Sejalan dengan penelitian yang dilakukan Yamamoto [15] yang meneliti tentang pembelajaran kosakata multidimensional, penggunaan flashcard dinilai efektif dalam pembelajaran penguasaan kosakata dalam deliberate learning. Lebih dari itu, flashcard dinilai dapat melatih beberapa keterampilan berbahasa lainnya seperti menulis, menyimak, dan membaca. Pemelajar BIPA level 1 merasa lebih tertantang, antusias, dan mampu lebih cepat menguasai kosakata secara dengan pengguanaan flashcard. Hal ini juga dibuktikan pada penelitian Anggreany [14] dan Kusuma [16] yang membutikan keefektifan flashcard dalam proses pembelajaran bahasa asing guna meningkatan penguasaan kosakata. Hasil menunjukkan bahwa media flashcard dinilai menjadi media yang efektif untuk pengenalan kosakata [17].

\section{SIMPULAN}

Hasil penelitian ini menunjukkan bahwa penguasaan kosakata pemelajar BIPA level I di UPT Bahasa UNS masih sangat rendah. Padahal, kata merupakan modal penting bagi seseorang dalam mempelajari suatu bahasa. Kesulitan-kesulitan Untuk itu, selain strategi pengajaran, diperlukan pula media pembelajaran yang tepat. Flashcard menjadi media yang dirasa praktis dan efektif guna memperkenalkan kosakata bahasa Indonesia pada pemelajar BIPA di UPT Bahasa UNS. Visual media flashcard dinilai dapat memudahkan pemelajar BIPA menggambarkan ilustrasi kosakata menjadi penunjang pembelajaran yang efisien bagi pemelajar BIPA. Selain itu, flashcard juga mampu melatih beberapa keterampilan berbahasa seperti menuli, menyimak, dan membaca. Penerapan media flashcard menjadi nilai tambah dalam pembelajaran bahasa di program BIPA UPT Bahasa UNS, khususnya dalam pengenalan kosakata.

\section{REFERENCES}

[1] M. Celce-Murcia, "Grammar Pedagogy in Second and Foreign Language Teaching," TESOL Q., 1991.

[2] N. Sudjana and A. Rivai, Media Pengajaran. 2009.

[3] A. Azhar, Media Pembelajaran. 2008.

[4] M. B. Miles and M. A. Huberman, Analisis Data Kualitatif: Buku Sumber Tentang Metode-Metode Baru. 2012.

[5] M. E. Komachali and M. Khodareza, "The effect of using vocabulary flash card on 
Iranian pre-university students' vocabulary knowledge,” Int. Educ. Stud., 2012.

[6] E. Chung, "Revisiting Second Language Vocabulary Teaching: Insights from Hong Kong In-Service Teachers," Asia-Pacific Educ. Res., vol. 27, no. 6, pp. 499-508, 2018.

[7] I. S. P. Nation, "Research into practice: Vocabulary," Lang. Teach., vol. 44, no. 4, pp. 529-539, 2011.

[8] L. Ortega, "Second language acquisition," in The Routledge Handbook of Applied Linguistics, 2011.

[9] R. Ramliyana, "Membangkitkan Motivasi Belajar Bahasa Indonesia bagi Penutur Asing (BIPA) Melalui Media Komik," Dialekt. J. Bahasa, Sastra, dan Pendidik. Bhs. dan Sastra Indones., 2016.

[10] H. D. Brown, "Teaching by Principles, Second Edition," Teaching by Principles An Interactive Approach to Language Pedagogy. 2007.

[11] J. MacAlister, "Pre-service teacher cognition and vocabulary teaching," RELC J., 2012.

[12] A. Buttner, Aktivitas Permainan Dan Strategi Penilaian Untuk Kelas Bahasa Asing. 2013.

[13] . Rudi Susilana and . Cepi Riyana, Media Pembelajaran: Hakikat, Pengembangan, Pemanfaatan dan Penilaian. 2009.

[14] F. Angreany and S. Saud, "Keefektifan Media Pembelajaran Flashcard Dalam Keterampilan Menulis Karangan Sederhana Bahasa Jerman Siswa Kelas Xi Ipa Sma Negeri 9 Makassar," Eralingua J. Pendidik. Bhs. Asing dan Sastra, vol. 1, no. 2, pp. 138-146, 2017.

[15] Y. Yamamoto, "Multidimensional vocabulary acquisition through deliberate vocabulary list learning," System, 2014.

[16] I. P. I. Kusuma, N. L. D. S. Adnyani, and G. A. P. Taharyanti, "Developing 10 Interesting Games as the Breakthrough of Monotonous Implementation of Flashcards to Vocabulary Learning and Assessments," Scr. J. J. Linguist. English Teach., vol. 2, no. 1, p. 68, Apr. 2017.

[17] K. Saddhono, Suhartatik, Bagiya, Widodo, and H. Wahyono, "Learning vocabularies using multimedia-based Teaching Indonesian to Speakers of Other Languages (TISOL)," in Journal of Physics: Conference Series, 2019, p. 012108. 